Diabetologia 10, 317-321 (1974)

(C) by Springer-Verlag 1974

\title{
Enteral Absorption of Water-in-Oil-in-Water Insulin Emulsions in Rabbits
}

\author{
M. Shichiri, Y. Shimizu, Y. Yoshida, R. Kawamori, M. Fukuchi, Y. Shigeta and H. Abe \\ First Department of Medicine, Osaka University Medical School, Osaka, Japan \\ Received: January 3, 1974, and in revised form: April 4, 1974
}

\begin{abstract}
Summary. Water-in-oil-in-water (W/O/W) insulin emulsions with a concentration of $100 \mathrm{U} / \mathrm{ml}$ of insulin were prepared, and the possible absorption of insulin in emulsion form was examined. The following results were obtained: $\mathrm{W} / \mathrm{O} / \mathrm{W}$ insulin emulsions were quite resistant to proteolytic enzymes in vitro. In the presence of pancreatic lipase, however, $\mathrm{W} / \mathrm{O} / \mathrm{W}$ insulin emulsion gradually lost its activity by the action of proteolytic enzymes. When administered to the jejunum at doses over $10 \mathrm{U} / \mathrm{kg}$, a significant and consistent increase in plasma insulin was observed, followed by a fall in blood glucose. The infusion of $\mathrm{W} / \mathrm{O} / \mathrm{W}$ insulin emulsions into the jejunum was three to four times more effective than
\end{abstract}

the administration of aqueous insulin. Insulin, when administered to the stomach, did not cause hypoglycemia at doses up to $150 \mathrm{U} / \mathrm{kg}$. When $\mathrm{W} / \mathrm{O} / \mathrm{W}$ insulin emulsions were administered orally, on the other hand, definite responses were observed in 3 out of 7 rabbits with 100 $\mathrm{U} / \mathrm{kg}$ and in 4 out of 7 rabbits with $150 \mathrm{U} / \mathrm{kg}$. For developing an effective method for oral administration of insulin, the present results indicate a possible means of protecting insulin molecule from proteolytic destruction, and of facilitating intestinal absorption of insulin.

Key words: Water-in-oil-in-water emulsions, insulin, enteral absorption, hypoglycemia, plasma insulin, rabbit.
As judged by plasma insulin and hypoglycemic responses, we have demonstrated that insulin can be absorbed from the intestine of mammals in a physiologically active form $[1-3]$. In these experiments, the hypoglycemic effect is most marked in the rabbits with Thiry-Vella loop, into which no pancreatic secretion entered, but the fraction absorbed is relatively small [1]. The relatively small absorption of insulin is, therefore, attributable either to inactivation of the major portion by intestinal proteolytic enzymes or inherent physical obstacle to diffusion imposed by the protein character of insulin.

To facilitate enteral absorption of insulin, representative attempts have been directed to main objectives; 1. inhibition of proteolytic enzymes, 2. increase in permeability of the intestinal wall. We have attempted to prepare insulin derivatives or substitutes which are not affected by digestive enzymes $[4,5]$. It is interesting to note the possible use of water-in-oil-in-water emulsions as a means of facilitating gastrointestinal absorption of normally non-absorbed water soluble biopolymers. Engel et al. [6] reported that intraduodenal injection of such an emulsion containing insulin resulted in a significant hypoglycemic activity in rats. In their experiments, however, the enteral absorption of water-in-oil-in-water insulin emulsions was measured only indirectly by measuring the hypoglycemic response. A more direct approach can be made by measuring plasma insulin concentrations.

To obtain additional information on the enteral absorption of insulin, we have prepared water-in-oilin-water insulin emulsions with a concentration of $100 \mathrm{U} / \mathrm{ml}$ of insulin and analyzed the efficiency of intestinal administration of such emulsions biologically and immunologically in rabbits. The effectiveness of oral administration of such emulsions was also examined.

\section{Materials and Methods}

Preparation of water-in-oil-in-water $(\mathrm{W} / \mathrm{O} / \mathrm{W})$ insulin emulsions:

A method for preparing $\mathrm{W} / \mathrm{O} / \mathrm{W}$ insulin emulsions [6] was modified as follows. Insulin solution $(26.4 \mathrm{U} /$ mg, bovine crystalline insulin, Sigma Chem. Co.), $1000 \mathrm{U} / \mathrm{ml}$, was made in $0.003 \mathrm{M} \mathrm{ZnCl}_{2}$ at $\mathrm{pH} 2.2$. The oil phase was $0.03 \mathrm{M}$ palmitic acid in octyl-decyl triglyceride (Nisshin Seiyu Co., Japan). The oil phase $(12 \mathrm{ml})$ was placed in a beaker, sonification was begun and the insulin solution $(8 \mathrm{ml})$ was allowed to drain from a pipette into the beaker. Sonification was continued for about 20 sec with a sonifier (model USV$3000 \mathrm{~V}, 22 \mathrm{KHz})$. This resulted in a water-in-oil (W/O) insulin emulsions. Twenty milliliter of the resulting W/O emulsions was added to a second aqueous phase $(60 \mathrm{ml})$ containing $1 \%$ sodium lauryl sulfate (Nikko Chem. Co., Japan). Sonification was carried out for 20 sec. The resulting emulsions (W/O/W insulin emulsions) was adjusted to $\mathrm{pH} 6.5$ with dilute $\mathrm{NaOH}$ and stored at $4^{\circ} \mathrm{C}$ for up to one month. The W/O/W insulin emulsions thus prepared contained insulin at a concentration of $100 \mathrm{U} / \mathrm{ml}$ emulsions. In a preliminary experiment, no demonstrable loss of insulin activity was observed after sonification of insulin solution. Insulin free emulsions were prepared as a control.

Extraction of insulin from $\mathrm{W} / \mathrm{O} / \mathrm{W}$ insulin emulsions: 
To extract insulin from $\mathrm{W} / \mathrm{O} / \mathrm{W}$ insulin emulsions, a method described by Grodsky and Forsham [7] was modified as follows. A mixture of $0.5 \mathrm{ml}$ of $\mathrm{W} / \mathrm{O} / \mathrm{W}$ insulin emulsions and $9.5 \mathrm{ml}$ of acidic alcohol $(15 \mathrm{ml}$ of $12 \mathrm{~N}$ hydrochloric acid diluted to one liter with $75 \%$ ethanol) was agitated for overnight at $4^{\circ} \mathrm{C}$ and centrifuged for $20 \mathrm{~min}$ at $10000 \mathrm{rpm}$. After centrifugation the precipitate was extracted again. The two supernatants were combined and adjusted to $\mathrm{pH} 8.5$ to 9.0 with concentrated ammonium hydroxide. The supernatant thus obtained was poured into 15 volumes of cold acetone, and the mixture was chilled overnight at $4^{\circ} \mathrm{C}$. After centrifugation the precipitate was dried in vacuum until the time of insulin assay. During the extraction from $\mathrm{W} / \mathrm{O} / \mathrm{W}$ insulin emulsions incubated with proteolytic enzymes, a very small amount of insoluble proteins was precipitated when acidic alcohol was adjusted to $\mathrm{pH} 8.5$. After $30 \mathrm{~min}$ at $4^{\circ} \mathrm{C}$, insoluble proteins were removed by centrifugation. In the present experiments, no demonstrable interference with the insulin assay was observed in the extract from insulin free emulsions incubated with proteolytic enzymes.

The extraction of $\mathrm{W} / \mathrm{O} / \mathrm{W}$ insulin emulsions with acidic alcohol resulted in approximately 80 to $86 \%$ recovery of insulin.

Hydrolysis of $\mathrm{W} / \mathrm{O} / \mathrm{W}$ insulin emulsions with proteolytic enzymes:

Pepsin (two times crystallized, $3200 \mathrm{U} / \mathrm{mg}$, Sigma Chem. Co.), $\alpha$-chymotrypsin (three times crystallized, 3200 U/mg, Sigma Chem. Co.), trypsin (lyophilized, $200 \mathrm{U} / \mathrm{mg}$, Worthington Biochem. Corp.) and pancreatic lipase (crude from hog pancreas, $90 \mathrm{U} / \mathrm{mg}$, Sigma Chem. Co.) were used in this experiment. $W / 0 /$ $W$ insulin emulsions containing $10 \mathrm{mg}$ of insulin were incubated for $3 \mathrm{~h}$ at $37^{\circ} \mathrm{C}$ with pepsin (weight ratio of substrate to enzyme, 200:1) in $0.2 \mathrm{M}$ citrate buffer, pH 2.2, and with $\alpha$-chymotrypsin (10:1), trypsin (10:1) and lipase ( $400: 1$ ) in $0.2 \mathrm{M}$ borate bufier, $\mathrm{pH}$ 8.0. Since pancreatic lipase preparation contained a small amount of trypsin, trasylol (Bayer Pharmaceutical Co.) was added in the digestion mixtures at a concentration of $2000 \mathrm{KIE} / \mathrm{ml}$ to inhibit tryptic activity. Aliquots of the incubation mixture were withdrawn at $0,60,120$ and $180 \mathrm{~min}$, and extracted for the assay of insulin.

Enteral administration of $\mathrm{W} / \mathrm{O} / \mathrm{W}$ insulin emulsions:

Male white rabbits, weighing from 2.0 to $2.5 \mathrm{~kg}$, were fasted overnight and divided at random into two experimental groups. In the first group of rabbits, W/O/W insulin emulsions were given through a polyethylene eatheter (diameter of $1.7 \mathrm{~mm}$ ) into the stomach. In the second group, an indwelling catheter was placed in the jejunal portion of the intestine by the technic described elsewhere [1]. W/O/W insulin emulsions with doses between 10 and $150 \mathrm{U} / \mathrm{ml} / \mathrm{kg}$ were infused into the gastrointestinal tract via a polyethylene catheter. Control rabbits received insulin free $\mathrm{W} / \mathrm{O} / \mathrm{W}$ emulsions. In the group with insulin solution, an equivalent dose of erystalline bovine insulin was given.

Blood samples were obtained from a marginal ear vein at $0,30,60,90,120,150$ and $180 \mathrm{~min}$, and the blood glucose was determined by the method of Somogyi-Nelson [8]. Immunoreactive insulin was measured by the method of Randle and Hales [9]. Insulin immunoassay kit was purchased from the Radiochemical Center, Amersham, England.

\section{Results}

\section{Properties of $W / O / W$ Insulin Emulsions}

The diameters of the W/O droplets in water were in the range of 0.6 to $2.0 \mu \mathrm{m}$. The degree of hydrolysis of $\mathrm{W} / \mathrm{O} / \mathrm{W}$ insulin emulsions by some proteolytic enzymes was studies in vitro. W/O/W insulin emulsions were quite resistant to the action of pepsin, $\alpha$-chymotrypsin and trypsin. In the presence of pancreatic lipase, however, $\mathrm{W} / \mathrm{O} / \mathrm{W}$ insulin emulsions gradually lost their activity by the action of proteolytic enzymes, so that about $33 \%$ of insulin activity was retained after $3 \mathrm{~h}$ incubation in vitro.

\section{Administration of W/O/W Insulin Emulsions to the Jejunum}

The hypoglycemic effects of $\mathrm{W} / \mathrm{O} / \mathrm{W}$ insulin emulsions given to the jejunum at doses of $10,20,40$ and $100 \mathrm{U} / \mathrm{kg}$ are shown in Table 1 . In rabbits with saline or W/O/W emulsions serving as control, the blood glucose levels increased gradually, but these changes were not statistically significant. When insulin with doses over $40 \mathrm{U} / \mathrm{kg}$ was infused into the jejunum via an indwelling catheter, there was a significant decrease in blood glucose. With W/O/W insulin emulsions, on the other hand, a significant and consistent decrease in blood glucose was found with doses over $10 \mathrm{U} / \mathrm{kg}$. As compared to the results with insulin, a greater fall in blood glucose and a longer duration of hypoglycemia were observed with $\mathrm{W} / \mathrm{O} / \mathrm{W}$ insulin emulsions.

The intrajejunal administration of insulin at doses over $40 \mathrm{U} / \mathrm{kg}$ increased the levels of insulin in plasma. On the other hand, a significant increase in plasma insulin was observed. when $10 \mathrm{U} / \mathrm{kg}$ of $\mathrm{W} / \mathrm{O} / \mathrm{W}$ insulin emulsions were infused. The magnitude of the increase varied with the dose given. With a dose of $100 \mathrm{U} / \mathrm{kg}$ of $\mathrm{W} / \mathrm{O} / \mathrm{W}$ insulin emulsions, the plasma insulin increased to a peak of $236 \mu \mathrm{U} / \mathrm{ml}$. As shown in Fig. 1, there was a significant correlation between the amount of $\mathrm{W} / \mathrm{O} / \mathrm{W}$ insulin emulsions infused and the plasma insulin responses (as reflected by the area under the plasma insulin curve).

Fig. 2 illustrates a comparison of mean blood glu. cose and plasma insulin levels following administration of insulin and $\mathrm{W} / \mathrm{O} / \mathrm{W}$ insulin emulsions at a dose of $100 \mathrm{U} / \mathrm{kg}$. The infusion of $\mathrm{W} / \mathrm{O} / \mathrm{W}$ insulin emulsions into the jejunum was three to four times more effective than the infusion of insulin solutions alone. 


\section{Oral Administration of $W / O / W$ Insulin Emulsions}

Administration of insulin into the stomach, with doses up to $150 \mathrm{U} / \mathrm{kg}$, did not change either the blood glucose or plasma insulin concentrations. The blood glucose and plasma insulin responses to oral administration of $\mathrm{W} / \mathrm{O} / \mathrm{W}$ insulin emulsions with doses of 100 and $150 \mathrm{U} / \mathrm{kg}$ were studied. At both doses, large variations of the blood glucose and plasma insulin concentrations were observed. Following administration of $100 \mathrm{U} / \mathrm{kg}$, the plasma insulin concentration in one rabbit (No. 4) was in excess of $200 \mu \mathrm{U} / \mathrm{ml}$, in two rabbits (No. 3 and 5) 58 and $39 \mu \mathrm{U} / \mathrm{ml}$ respectively, and in four other rabbits (No. 1, 2,6 and 7) neither plasma insulin nor blood glucose changed significantly.

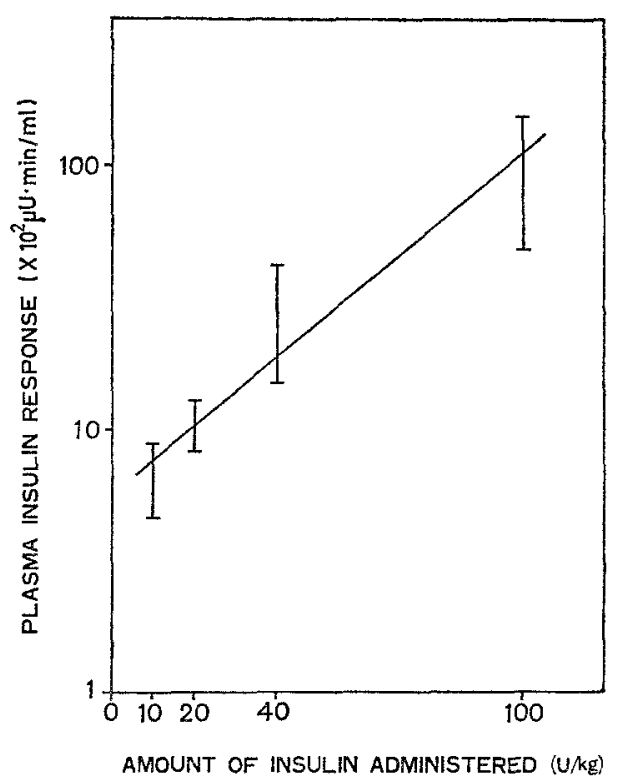

Fig. 1. Effect of different doses of $W / O / W$ insulin emulsions administered to the jejunum on the plasma insulin responses. The areas under the insulin curves were calculated during the three-hour experimental period after dosing. Vertical bars denote S.E. of the mean plasma insulin responses. Statistical analysis shows $\mathbf{r}=$ $0.730, p<0.01$

With $150 \mathrm{U} / \mathrm{kg}$, the plasma insulin concentration rose to a maximum of $225 \mu \mathrm{U} / \mathrm{ml}$ in one rabbit (No. 14), and the blood glucose decreased to a nadir of $28 \mathrm{mg} /$ $100 \mathrm{ml}$. In three rabbits (No. 8, 9 and 12), peak insulin concentration was between 50 and $150 \mu \mathrm{U} / \mathrm{ml}$. In two other rabbits (No. 10 and 11), plasma insulin rose only to about $20 \mu \mathrm{U} / \mathrm{ml}$, and in one rabbit (No. 13) plasma insulin did not change.

On the basis of plasma insulin responses (as reflected by the area), rabbits were classified as responders or non-responders. Definite responses were $o b$ served in 3 out of 7 rabbits with $100 \mathrm{U} / \mathrm{kg}$ and in 4 out of 7 rabbits with $150 \mathrm{U} / \mathrm{kg}$ (Table 2 ). In responders (with the exception of No. 12), peak insulin responses occurred between thirty and sixty minutes after $\mathrm{W} / \mathrm{O} /$ $\mathrm{W}$ insulin emulsions were given orally. Rabbit No. 12 showed peak insulin response at $120 \mathrm{~min}$.

\section{Discussion}

$\mathrm{W} / \mathrm{O} / \mathrm{W}$ insulin emulsions prepared originally by Engel et al. [6] contained insulin at a concentration of $10 \mathrm{U} / \mathrm{ml}$. In the process in preparing $\mathrm{W} / \mathrm{O} / \mathrm{W}$ insulin emulsions, $\mathrm{ZnCl}_{2}$ was added to stabilize $\mathrm{W} / \mathrm{O}$ emulsions, resulting in the formation of zinc-palmitate. At a

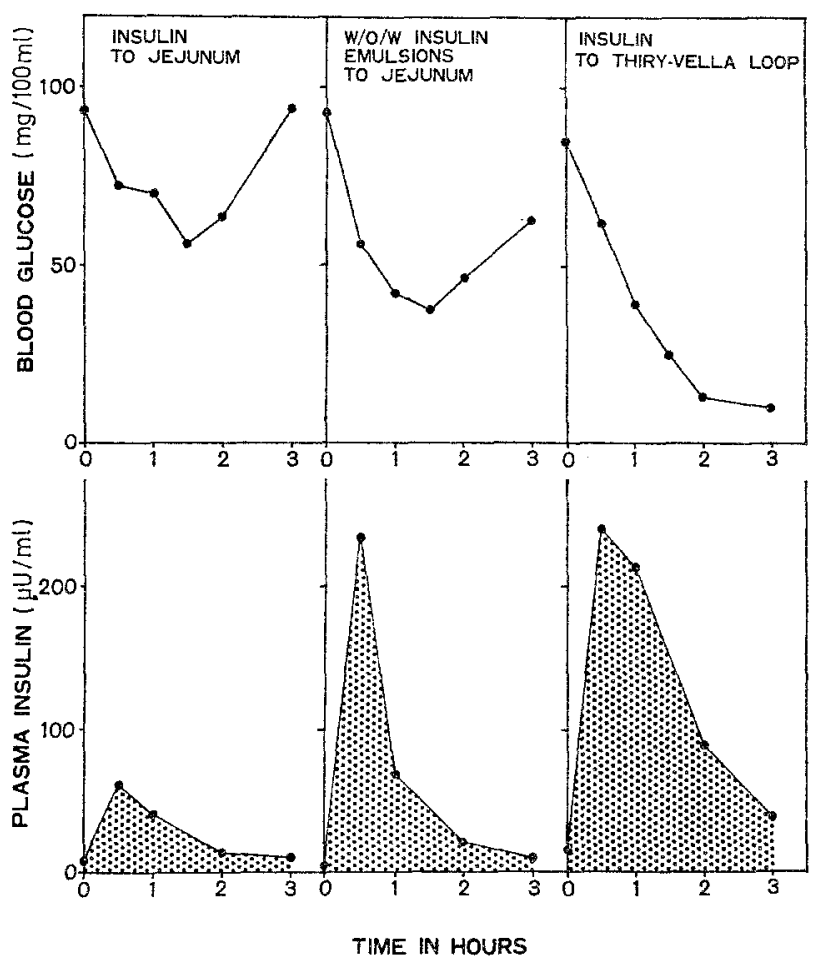

Fig. 2. Comparison of mean blood glucose and plasma insulin levels following administration of insulin or $\mathrm{W} / \mathrm{O} / \mathrm{W}$ insulin emulsions to the jejunum of rabbits at a dose of $100 \mathrm{U} / \mathrm{kg}$. The result of experiments with Thiry-Vella loop is described in a previous report [1]

higher concentration of insulin, however, zine ions bound insulin at the neutral $\mathrm{pH}$ to form zinc-insulin compounds. To obtain $\mathrm{W} / \mathrm{O} / \mathrm{W}$ insulin emulsions with a higher insulin concentration $(100 \mathrm{U} / \mathrm{ml})$, an acidic solution of insulin ( $\mathrm{pH} 2.2)$ was incorporated into a continuous oil phase (W/O emulsions) in the present experiments. The question arises whether the emulsions prepared are really $\mathrm{W} / \mathrm{O} / \mathrm{W}$ emulsions.

At the present time, reasonably precise methods are not available to answer this question. However, the fact that insulin added to the insulin free emulsions was easily destroyed by the proteolytic enzymes, while $\mathrm{W} / \mathrm{O} / \mathrm{W}$ insulin emulsions were not, indicates that insulin, was probably incorporated into the oil phase. 
Compared to the results with a simple insulin solution, a significant increase in plasma insulin concentration and longer duration of hypoglycemia were observed when $\mathrm{W} / \mathrm{O} / \mathrm{W}$ insulin emulsions were administered to the jejunum of rabbits. The plasma insulin responses, protecting insulin molecule, to some extent, from digestive destruction. The absorption of $\mathrm{W} / \mathrm{O} / \mathrm{W}$ insulin emulsions, however, might be small in relation to the dose of insulin given. To make a rough estimation as to the fraction of insulin absorbed, the plasma in-

Table 1. Changes in blood glucose and plasma insulin concentrations following a single administration of $W / O / W$ insulin emulsions to the jejunum of rabbits

\begin{tabular}{|c|c|c|c|c|c|c|c|c|c|c|c|c|c|}
\hline \multirow{2}{*}{$\begin{array}{l}\text { Experimental } \\
\text { condition }\end{array}$} & \multirow{2}{*}{ No. } & \multicolumn{6}{|c|}{ Mean blood glucose $(\mathrm{mg} / 100 \mathrm{ml})$} & \multicolumn{6}{|c|}{ Mean plasma insulin $(\mu \mathrm{U} / \mathrm{ml})$} \\
\hline & & 0 & 30 & 60 & 90 & 120 & $180 \min$ & 0 & 30 & 60 & 90 & 120 & $180 \mathrm{~min}$ \\
\hline \multicolumn{14}{|l|}{ Control } \\
\hline Saline & 6 & 91 & 104 & 101 & 97 & 109 & 135 & 6 & 4 & 6 & - & 4 & 6 \\
\hline W/O/W Emulsions & 6 & 78 & 82 & 85 & 89 & 95 & 92 & 6 & 6 & 6 & 5 & 6 & 5 \\
\hline \multicolumn{14}{|l|}{$10 \mathrm{U} / \mathrm{kg}$} \\
\hline Insulin solution & 6 & 91 & 91 & 98 & 112 & 112 & 110 & 6 & 11 & 6 & - & 7 & 7 \\
\hline W/O/W Insulin & 6 & 98 & $79^{\mathrm{a}}$ & 81 & 88 & 96 & 92 & 6 & $17^{\mathrm{a}}$ & 11 & 9 & 9 & $\dot{9}$ \\
\hline \multicolumn{14}{|l|}{$20 \mathrm{U} / \mathrm{kg}$} \\
\hline Insulin solution & 5 & 88 & 84 & 87 & 83 & 96 & 97 & 7 & 14 & 7 & - & 8 & 8 \\
\hline $\mathrm{W} / \mathrm{O} / \mathrm{W}$ Insulin. & 6 & 106 & $71^{\mathrm{a}}$ & $73^{\mathrm{a}}$ & 78 & 91 & 98 & 5 & $25^{\mathrm{a}}$ & 11 & 10 & 8 & 7 \\
\hline \multicolumn{14}{|l|}{$40 \mathrm{U} / \mathrm{kg}$} \\
\hline Insulin solution & 5 & 83 & $58^{a}$ & $59^{a}$ & 69 & 79 & 115 & 7 & $22^{\mathrm{a}}$ & 17 & - & 8 & 5 \\
\hline $\mathrm{W} / \mathrm{O} / \mathrm{W}$ Insulin & 5 & 99 & $55^{\mathrm{a}}$ & $58^{\mathrm{a}}$ & $57^{\mathrm{a}}$ & $71^{\mathrm{a}}$ & 86 & 7 & $64^{\mathrm{a}}$ & $30^{\mathrm{a}}$ & $29^{a}$ & 15 & 10 \\
\hline \multicolumn{14}{|l|}{$100 \mathrm{U} / \mathrm{kg}$} \\
\hline Insulin solution & 7 & 94 & 72 & $70^{a}$ & $56^{\mathrm{a}}$ & $64^{\mathrm{a}}$ & 94 & 6 & $63^{a}$ & $38^{\mathrm{a}}$ & - & 13 & 10 \\
\hline W/O/W Insulin & 5 & 93 & $56^{\mathrm{a}}$ & $42^{b}$ & $38^{\mathrm{a}}$ & $47^{\mathrm{a}}$ & $63^{a}$ & 4 & $236^{\mathrm{b}}$ & $68^{a}$ & $39^{a}$ & $20^{\mathrm{a}}$ & 11 \\
\hline
\end{tabular}

Insulin solution or $\mathrm{W} / \mathrm{O} / \mathrm{W}$ insulin emulsion was given through an indwelling catheter to the upper jejunum. As a control, saline solution or insulin free $\mathrm{W} / \mathrm{O} / \mathrm{W}$ emulsion was infused. The coefficients of variation: $20.3 \%$ of the mean blood glucose and $43.8 \%$ of the mean plasma insulin.

a $p<0.05$, as compared with a baseline level in each group.

b $p<0.05$, as compared with insulin solution.

Table 2. Plasma insulin responses to oral administration of W/O/W insulin emulsions in rabbits

\begin{tabular}{lcc}
\hline $\begin{array}{l}\text { Experimental } \\
\text { conditon }\end{array}$ & $\begin{array}{l}\text { Rabbits } \\
\text { No. }\end{array}$ & $\begin{array}{c}\text { Plasma insulin responses } \\
\left(\mathrm{X} 10^{2} \mu \mathrm{U} \cdot \mathrm{min} / \mathrm{ml}\right)\end{array}$ \\
\hline W/O/W Insulin & 1 & 3.9 \\
$\left(100 \mathrm{U} / \mathrm{kg}^{\prime}\right)$ & 2 & 9.6 \\
& 3 & $26.9^{\mathrm{a}}$ \\
& 4 & $103.5^{\mathrm{a}}$ \\
& 5 & $22.2^{\mathrm{a}}$ \\
& 6 & 1.4 \\
W/O/W Insulin & 8 & 0.3 \\
$(150 \mathrm{U} / \mathrm{kg})$ & 9 & $34.7^{\mathrm{a}}$ \\
& 10 & $32.1^{\mathrm{a}}$ \\
& 11 & 7.7 \\
& 12 & 6.9 \\
& 13 & $51.9^{\mathrm{a}}$ \\
& 14 & 2.9 \\
\hline
\end{tabular}

Insulin solution or $W / O / W$ insulin emulsion was given through a stomach tube to the stomach.

a The plasma insulin responses, as reflected by the area, increasd significantly from the variation of control exporiments (an upper $95 \%$ confidence limit for the control: $\left.18.8 \times 10^{2} \mu \mathrm{U} \cdot \mathrm{min} / \mathrm{ml}\right)$

however, were less than those after insulin infusion into the Thiry-Vella loop into which no pancreatic secretion entered [1]. The results with $\mathrm{W} / \mathrm{O} / \mathrm{W}$ insulin emulsions, therefore, might possibly be explained either by facilitating gastrointestinal absorption or by sulin responses after intestinal administration (as reflected by the area under the plasma insulin curves) was compared to that after intramuscular injection. Approximately 0.4 to $1.2 \%$ of $\mathrm{W} / \mathrm{O} / \mathrm{W}$ insulin emulsions were absorbed from the intestine. These data were three to four times as much as those of intrajejunal administration of insulin solution (0.1 to $0.4 \%$ ), and about half as much as that of insulin infusion into the Thiry-Vella loop (0.8 to $2.5 \%$ ) [1]. Since insulin in the present preparation is protected from digestive destruction, other factors may be more important in contributing to the small absorption of insulin. One might consider the physical barriers to transport across the intestinal wall.

The lack of hypoglycemic and plasma insulin responses after oral administration of insulin is not surprising, since gastric juice inactivates insulin. $\mathrm{W} / \mathrm{O} / \mathrm{W}$ insulin emulsions were found to be resistant to the action of pepsin in vitro. This fact suggested the possibility that $W / O / W$ insulin emulsions might be effective by mouth. In the present experiments, large variations of the blood glucose and plasma insulin responses were found after oral administration of $\mathrm{W} / \mathrm{O} / \mathrm{W}$ insulin emulsions. Definite responses were observed in 3 out of 7 rabbits with $100 \mathrm{U} / \mathrm{kg}$ and in 4 out of 7 rabbits with $150 \mathrm{U} / \mathrm{kg}$. The peak insulin responses also varied between 30 and $120 \mathrm{~min}$ after dosing. Factors which might be responsible for the large varia- 
tions of responses to oral administration of $\mathrm{W} / \mathrm{O} / \mathrm{W}$ insulin emulsions could not be fully evaluated in the present experiments.

Since dietary triglycerides are not appreciably affected by any of the enzymatic process until the fat reaches the small intestine [10], the observed effect after oral administration of $\mathrm{W} / \mathrm{O} / \mathrm{W}$ insulin emulsions might be considered as the intestinal absorption of insulin after reaching the duodenum. The exact mechanism of intestinal absorption of $\mathrm{W} / \mathrm{O} / \mathrm{W}$ insulin emulsions is at the present time unknown. It is now widely accepeted that pancreatic lipases act at the interface of emulsion particles, resulting in the formation of negatively charged polymolecular aggregates termed "micelles". The size of the micelle $(40-50 \AA)$ is small enough to allow free access to the intermicrovillous space, which are approximately 500-1000 $\AA$ [10]. When $W / O / W$ insulin emulsions were infused into the Thiry-Vella loop, a significantly lower and delayed response was observed as compared to those of insulin infusion. It seems, therefore, unlikely that insulin in emulsion form is capable of penetrating the limiting membrane of the intestinal mucosa. No conclusions were drawn from the present studies as to whether or not $\mathrm{W} / \mathrm{O} / \mathrm{W}$ insulin emulsions were absorbed from the intestine in the form of micelles, and whether or not insulin was released from the emulsified or micellar form prior to its absorption.

Present results, however, indicate a possible means of protecting insulin molecule from proteolytic destructions, and of facilitating intestinal absorption of insulin. For developing oral insulin preparations, further studies are necessary to elucidate the possible interactions of components (surfactant, oil and insulin) in $\mathrm{W} / \mathrm{O} / \mathrm{W}$ insulin emulsions.

Acknowledgement. This study was supported by a grant from the Ministry of Education, Japan (Grant No. 857099). We are indebted to Dr. Hiroitsu Kawata, (Central Research Laboratory, Yamanouchi Pharmaceutical Co., Ltd., Tokyo, Japan) for the preparation of $\mathrm{W} / \mathrm{O} / \mathrm{W}$ insulin emulsions. The technical assistance of Miss Tomoko Kikuchi is gratefully acknowledged.

\section{References}

1. Shichiri, M., Okada, A., Karasaki, K., Kawamori, R., Shigeta, Y., Abe, H.: Increase in plasma immunoreactive insulin following administration of insulin to the gastrointestinal tract of rabbits. Diabetes $\mathbf{2 1}$ $203-208(1972)$

2. Shichiri, M., Etani, N., Kawamori, R., Karasaki, K., Okada, A., Shigeta, Y., Abe, H.: Absorption of insulin from perfused rabbit small intestine in vitro. Diabetes 22, $459-465$ (1973)

3. Shichiri, M., Okada, A., Kawamori, R., Etani, N., Shimizu, Y., Hoshi, M., Shigeta, Y., Abe, H.: Portal vein insulin responses to the intestinal administration of insulin in rabbits. Endocrinology 93, 131-137 $(1973)$

4. Shichiri, M., Okada, A., Kikkawa, R., Kawamori, R., Shigeta, Y., Abe, H: : $\beta$-naphthyl-azo-polystyreneinsulin as a means of protecting insulin molecule from digestive enzymes. Biochem. biophys. Res. Commun. 44, $51-56(1971)$

5. Shigeta, Y., Shichiri, M., Okada, A., Karasaki, K. Plasma immunoreactive insulin after intestinal administration of $\beta$-naphthyl-azo-polystyrene-insulin to the rabbit. Endocrinolog'y 91, 320-322 (1972)

6. Engel, R.H., Riggi, S.J., Fahrenbach, M.J.: Insulin: intestinal absorption as water-in-oil-in-water emulsions. Nature 219, 856-857 (1968)

7. Grodsky, G.M., Forsham, P.H.: An immunochernical assay of total extractable insulin in man. J. clin. Invest. 39, 1070-1079 (1960)

8. Nelson, N.: A photometric adaptation of the Somogyi method for the determination of glucose. J. biol. Chem. 153, 375 (1944)

9. Hales, C.N., Randle, P.J.: Immunoassay of insulin with insulin-antibody precipitate. Biochem. J. 88, $137-146(1963)$

10. Florkin, M., Stotz, E.H.: Lipid Metabolism, p. 1. New York: Elsevier 1970

Motoaki Shichiri, M.D.

First Dept. of Medicine

Osaka University Medical School

Dojimahamadori

Fukushima-Ku

Osaka

Japan 